\title{
Potential for Transformation of Urban Open Public Spaces in Modernist Multi-Apartment Districts in Lithuania
}

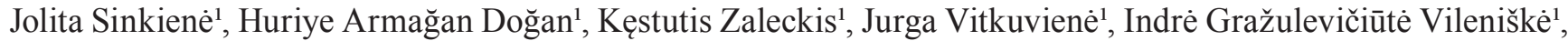 \\ Brigita Tranavičiūtè ${ }^{1}$, Tomas Grunskis ${ }^{2}$ \\ ${ }^{1}$ Kaunas University of Technology, Kaunas, Lithuania, ${ }^{2}$ Vilnius Academy of Arts, Vilnius, Lithuania
}

\begin{abstract}
This paper presents the methodology and results of the research aimed to identify the current and potential functions of open public spaces in post-Soviet modernist urban districts in the context of sustainable urban development. The research is based on the sociotope mapping methodology facilitating the identification and interpretation of functional characteristics of urban open public spaces. The data for this research has been collected in three selected pilot multi-apartment modernistic districts of Kaunas city (Lithuania) using two sociological research tools - site observation protocols and user questionnaires. The research results show the need for actors involved in planning and (re)development of modernistic districts to incorporate a larger diversity of space elements enabling different local area users (individuals, families, organizations) to use and experience more natural, social, economic and other values available locally at different time (year, day) periods.
\end{abstract}

Keywords - Modernization, open public spaces, sociotope mapping methodology, sustainable city.

\section{INTRODUCTION}

Cities are and will continue to be the home of majority of global population. They are hubs of humanity's greatest achievements as well as the centres of most complex issues bringing unprecedented challenges to the planet's sustainability [1]. The world's cities are major actors of the global sustainability agenda. The global Sustainable Development Goal No.11 calls to "make cities inclusive, safe, resilient and sustainable" [2].

A large number of studies on urban sustainability deal with social and economic aspects, i.e. the "soul" of the city [3], [4], yet there is still a lack of attention to its "body", i.e. its physical form, structure, space distribution and its use represented by the built environment within a city [5]. The two realms have a direct interrelation and have impact on each other as well as on the third realm - the surrounding natural environment [6, 149-166]. Urban sustainability cannot be achieved without a rational form and functions of a city. How to achieve this aim?

Many cities, especially those who have undergone a soviet occupation period, have large inner territories planned according to the modernistic ideology and practice. There the local population for a long time had little or no voice in organizing their living space. Instead, planning was perceived as a technical activity to be carried out by trained experts without the involvement of other decision makers or communities [7, 49]. This "closed doors" practice led to a situation where open public spaces, especially in modernistic multi-apartment districts, were left without an "owner" able to initiate and implement the desired transformation of the space that was used daily. From the one hand, this owner in most cases is the "society" (represented by the state or local authorities and their institutions), yet the actual user is local resident and/or their groups still having rather limited possibilities to express and fulfil their needs for the functions of this important space and to transform it. If the urban development had not been planned by concerning the people and their lifestyles, it is likely that it would have failed in the long-term. In that regard, it is essential for all urban development actors to employ a clear and effective planning methodology where the first and most important task is to analyse the needs and requirements of local residents and other local space users.

In 2017, the national programme "Create Lithuania" implemented a nation-wide research [8] aimed to diagnose if Lithuanian cities and settlements are being developed sustainably. $87 \%$ of the respondents stated that Lithuanian cities are developing unsustainably and the following two factors were indicated as major barriers: "culture of planning and competences" (27\%), and "urban planning and design" (17\%). The research concluded: "There is a lack of competences of municipal officials, urban developers and infrastructure users about the subject of sustainable development; the urban policy is inadequate, there is a lack of involvement of community into the planning process and urban design is not based on the needs of residents".

Most international and national debates on strategies for sustainable development of cities emphasize the demand for a more efficient connection between the world of planners and the real world of citizens, starting from the users' space and perspective, not the planners' [9].

To contribute to this debate, a group of researchers representing arts (architecture, urban planning), humanities (history) and social sciences (public management, sociology) from Kaunas University of Technology (Lithuania) initiated an interdisciplinary research with the aim to identify and evaluate the changes in the social-spatial genotype of the major cities of Lithuania influenced by the Soviet-era modernistic urbanization (period 1960-1990-2018). The research involves interdisciplinary network theory, mathematical network models, sociological analysis (content analysis of archive and contemporary materials, sociotope mapping, and other).

This paper presents the methodology and results of one stage of general research (a sociological research), which aimed to identify and assess the functions available for local users in modernist urban spaces in multi-apartment blocks developed during 
the Soviet era in Kaunas city (second-largest city of Lithuania) and to provide insights and recommendations for urban planning scholars, practitioners as well as policy makers involved in (re) development of Soviet-era modernist multi-apartment districts on how to make these districts and cities more functional and sustainable.

\section{Methodology}

To achieve the aim of the sociological research, general logics and main tools of sociotope mapping methodology [9] were applied. Kaunas, the second largest city of Lithuania (area $157 \mathrm{~km}^{2}$, population 292677 ), was selected to test the methodology before applying it in modernistic districts of two other Lithuanian cities (Vilnius and Klaipeda).

The methodology of sociotope mapping was developed by Swedish urban planners in the context of changing urban planning paradigm and shifting from functionalist and modernist urban planning to compact city, where numerous conflicts of functions, uses, and values occur. Here urban planner increasingly becomes a facilitator of other people's needs, values and views and sociotope map is used as a way of understanding and visualizing social values in urban space. It has been developed and applied in Stockholm [9], [10], Goteborg [11], Kungsbacka [12], Sollentuna [13], and elsewhere.

The term "sociotope" derives and is an extension of the term "biotope", whereas the sociotope is seen as a place of human activities, a distinct environment in its sociocultural context. The main purpose of such map is to collect through dialogue, enhance and disseminate the knowledge of how open public spaces such as parks, squares, piers, beaches, playgrounds, tracks, pedestrian zones and other function as habitats for the people who live and work in the city [14].

For Kaunas city sociotope analysis three city districts (local neighbourhoods), known for the large modernist multi-apartment housing stock, were selected [15]: Silainiai (area $-25 \mathrm{~km}^{2}$, 50000 inhabitants, development started in 1984, extensively built-up area with 422 typical Soviet-era residential multi-apartment buildings); Eiguliai (area - $14.5 \mathrm{~km}^{2}, 41000$ inhabitants, development started in 1978337 multi-apartment buildings); and Naujamiestis (meaning "The New Town”, area $-3.14 \mathrm{~km}^{2}$, development started in 1847, part of the central district of the city). The districts represent three important time periods of modernistic planning and development of Kaunas city (first half of the 20th century, years 1980 and 1990). The differences in the area size and their location in the city served as two other criteria for the choice of districts for the survey.

Two methods and tools were developed and applied to collect the required data from the areas.

Method 1. Expert observation sessions on site to identify how the selected open public spaces are used (tool - observation protocol).

The content of the protocols was identical to the sample of observation protocol provided in the sociotope mapping methodology [14]. The experts (architect/urban planner and urban sociolo- gist) visited the sites twice during a 6 months period - in autumn (October) of 2017 and spring (May-June) of 2018 during the day time on workday and in week-end. 42 criteria of public space usage activities proposed by the authors of the original sociotope mapping research methodology [9] and classified into 9 groups (public space type, form, identity, recreational use, security, participation, supply, temporality, space structure) are the basis of the content of the observation protocol. Using the protocols, the researchers-experts assessed (twice) 20 public spaces of the three districts of Kaunas city. Both typical and unique functions and values of the use of the explored public spaces were identified. The potential for their (re)development and new adaptation to the needs of local users was identified.

Method 2. Questionaire (on-line, paper) on how the open space is and can be used (tool-questionnaire template).

This questionnaire template was developed as a result of combination of four separate questionnaire templates used in original sociotope mapping methodology in Stockholm city [14] aimed at collecting the information from four age groups of the local residents: children, youth, adults, and elderly. Authors of this research developed one general questionnaire template addressing all groups of respondents in one. Several additional questions relevant for the wider interdisciplinary research were added. The final questionnaire template consists of 15 questions. The templates were distributed and filled in during a 6 months period (November 2017 - May 2018). The forms were distributed physically (paper templates were given to members of local educational institutions, local residents) and via electronic channels (e-mail, Facebook accounts of most active local community groups, community administration, local institutions). An electronic questionnaire was placed on the www.apklausa. It site (a national web portal specializing in social surveys). In total 315 questionnaires were completed (for Naujamiestis District 101, for Eiguliai District - 113, for Silainiai District - 102). By summarizing the results of this survey, the most and least visited zones of public spaces, their functions in different seasons and at different times of the day were determined, and the potential values of these zones were identified.

\section{Results and Discussion}

The data collected with the help of observation protocols in the target 20 open public spaces of three selected Kaunas multi-apartment districts (Research method 1) provide the following data and information (an excerpt from the general research report is provided in this publication).

Park/field function (40\%) dominates in the open spaces of observed territories. Culture functions are evident in just several sites $(15 \%)$. The least developed function in most observed open public zones is related with water - canals $(0 \%)$ and other forms of access to water (4\%) are very rare (Fig. 1).

In majority of observed cases the open public space is developed for pedestrian passage paths (32\%); the next most popular types of spaces are courtyards (21\%), squares (19\%) and sports fields (17\%). Access to rocks, mountains/hills, as well as 


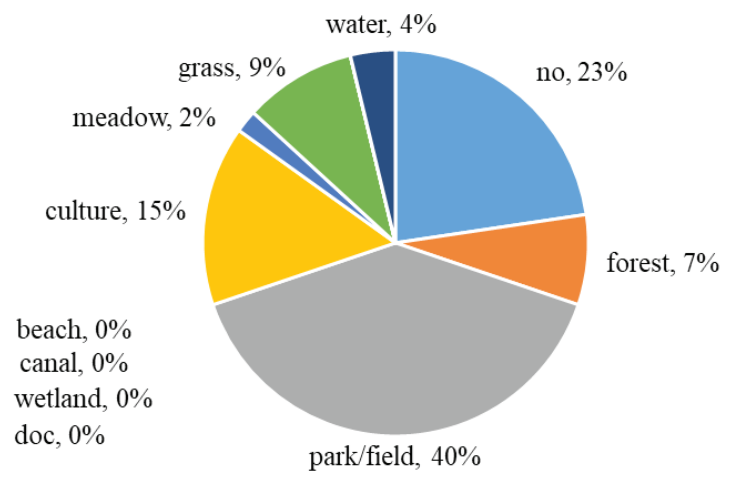

Fig. 1. Types of open public spaces [Picture: Authors of the Article].

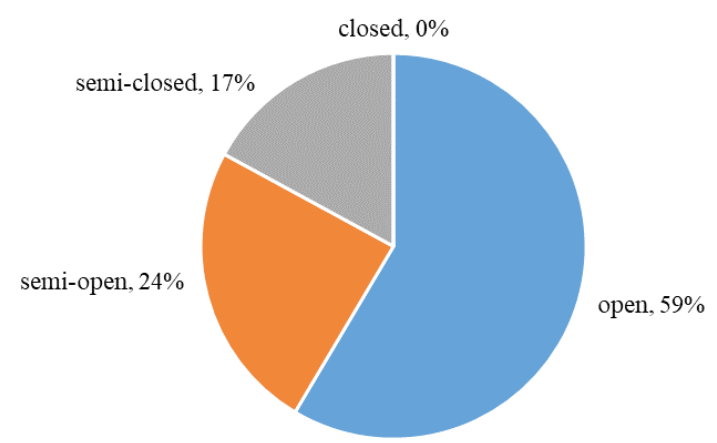

Fig. 3. Level of openness of the space [Picture: Authors of the Article].

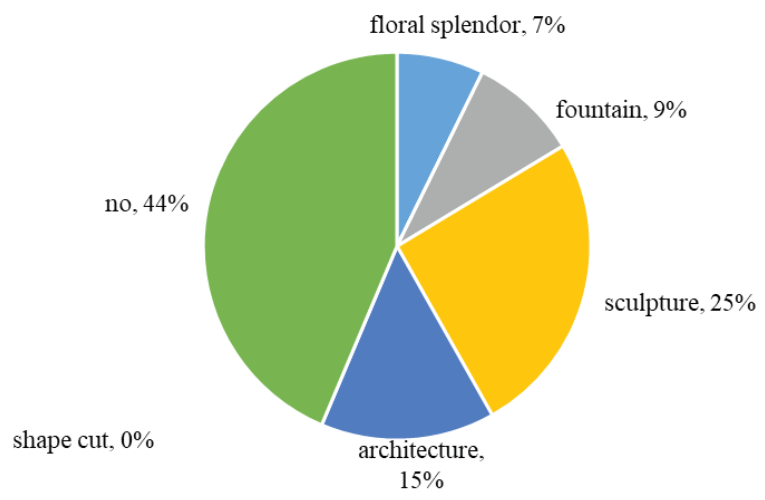

Fig. 5. Art work in open public spaces [Picture: Authors of the Article].

water (shores, piers) are not available in the target zones due to natural local conditions (Fig. 2).

Open public spaces (59\%) dominate in the surveyed spaces in Kaunas multi-apartment districts (Fig. 3). No spaces devoted to district residents' use were closed for public access during the daytime or night time.

The ground cover of spaces determines and/or restricts its possible use and function. The ground of majority of surveyed public open spaces (Fig. 4) is covered with asphalt (32\%). 1/5 of the areas are covered with grass. Stone $(15 \%)$ and shrubs $(15 \%)$

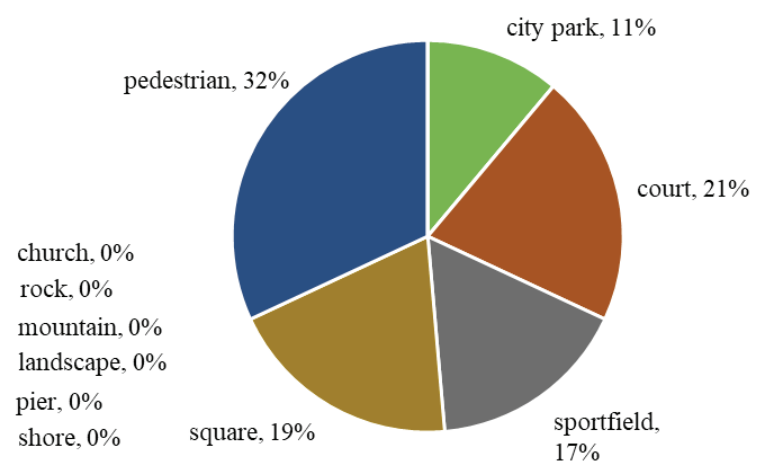

Fig. 2. The dominant functions in the open public spaces [Picture: Authors of the Article].

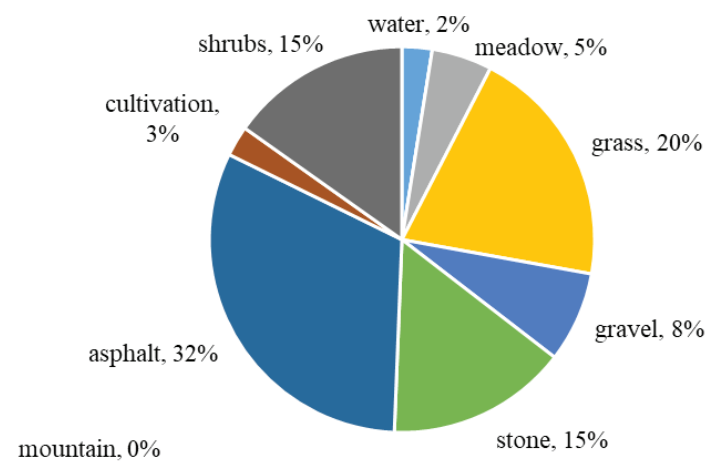

Fig. 4. Type of ground of the area [Picture: Authors of the Article].

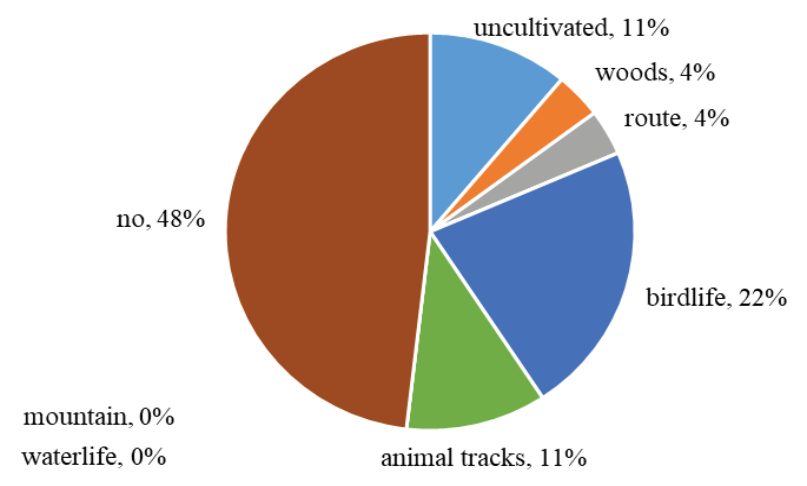

Fig. 6. Access to wild nature in open public spaces [Picture: Authors of the Article].

are popular elements as well. The local residents and visitors lack possibilities to perform daily recreational and other activities in public spaces in/on/near the water, meadows, the grass or rock (the last material is not naturally accessible in Kaunas and Lithuania in general).

Almost half(44\%) of the observed public spaces (Fig. 5) lack art work. Where it exists, sculptures are dominating (25\%). In 3 (out of 20) spaces water fountains are installed. There is a great lack of flowers (only $7 \%$ of spaces have flower plants). 


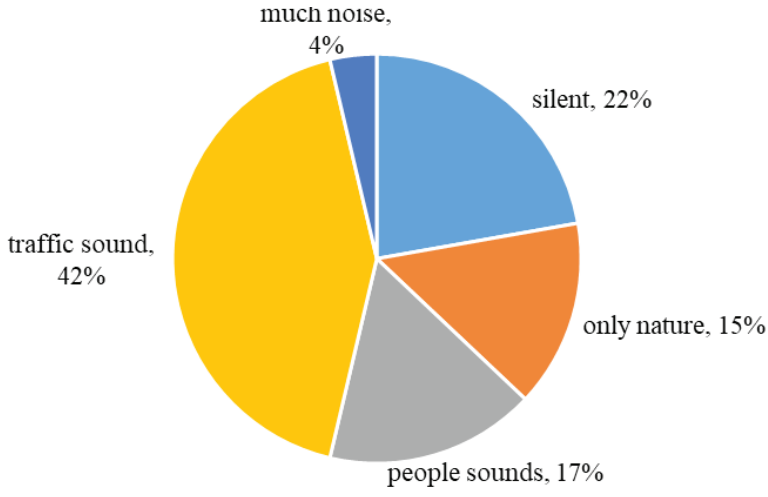

Fig. 7. Types of sound in observed public open spaces [Picture: Authors of the Article].

There are very limited possibilities (48\%) to observe wild animals, birds, fish, plants and other wild nature elements (on the ground, in the air or in the water) when staying in the observed public open spaces (Fig. 6). The most realistic possibility is to watch birdlife (22\%), whereas the possibilities of local residents to observe the water life are very small.

The survey showed that in most open public spaces the sound is an issue to be addressed (Fig. 7). In order to motivate local users to spend more quality time outside their private spaces (homes, offices, clubs, shops, etc.) in any time of the year, it is important to assure that the environment is pleasant and comfortable. The high level of noise is an important obstruction. In observed public open spaces the main source of high noise level is street traffic (42\%). Yet there is a reasonable choice of silent spaces (22\%) or spaces with only nature sounds $(15 \%)$, too.

The best opportunities to experience togetherness in the observed open public spaces have children (50\%). There is a well-developed infrastructure for games and other physical activities of children in most parks, squares, yards and other recreational zones. However, residents of other age groups, especially youth and elderly, have very limited possibilities to spend their leisure time alone or in a group in the nearby open public space.

Analysis of other observation objects of this research prove that there is a lack of supply of serving and service functions (such as cafes, kiosks, outdoor WC, barbeque zones, market, shops, other trade, etc.); also the conditions for water and all types of winter activities in the areas must be improved.

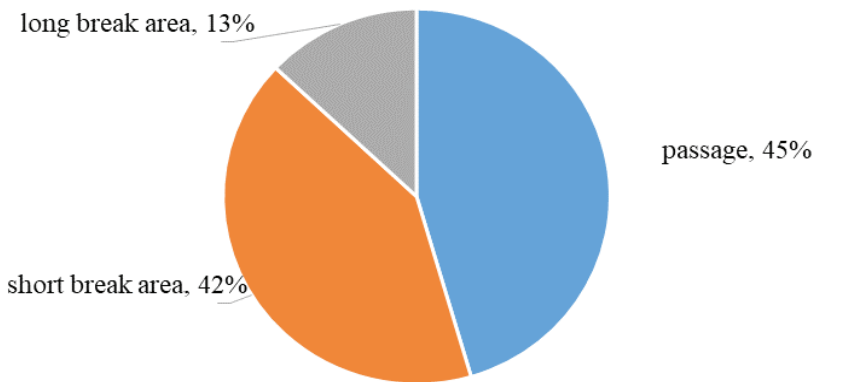

Fig. 9. Length of stay in the surveyed open public spaces [Picture: Authors of the Article].

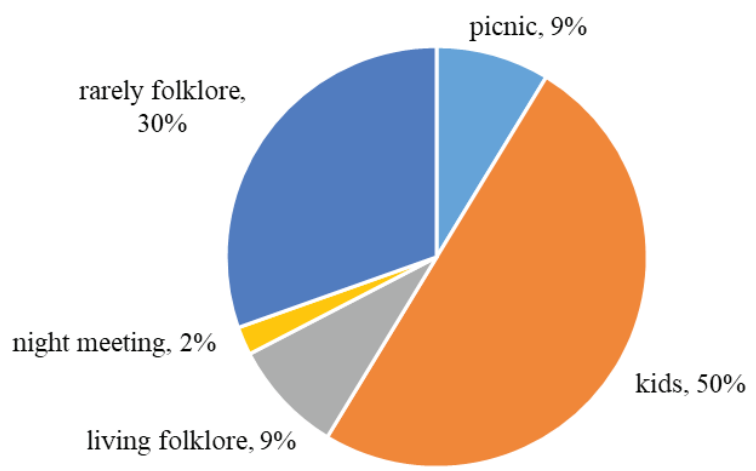

Fig. 8. Cases of togetherness in the surveyed spaces [Picture: Authors of the Article].

Therefore, most often open public spaces are being used just for passage (45\%) instead of long-term (currently - $13 \%$ ) or short-term (currently - $42 \%$ ) stay and for experiencing different kinds of activities in the open air (Fig. 9).

The analysis showed that despite the significant differences of the three modernist districts (based on the period of their development, area size and geographical (natural) location), very similar characteristics of the public spaces can be emphasized. There is a clear need for (re)development of the spaces to provide more diversity and balance in the functions for both group and individual use: culture, sports, gathering, entertainment, relaxation, wild nature observation ( plants, birds, water, animals, etc.).

If more natural materials (stone, brick, wood) were used for pathways, courtyards, squares and stairs and less asphalt, it would create a more natural and therefore more attractive outdoor environment for its users. Various art elements - both permanent art objects and also art activities - should be introduced in the modernistic public spaces of Kaunas more intensively. In other words, the planning of open spaces should aim to provide well-balanced possibilities for different users (individual and groups representing all ages and interests), for different functions (leisure, learning, culture, sports, work, movement, etc.), at different times of the day and year. Achieving this aim would allow to correct the mistakes of the previous planning strategies and to achieve a more sustainable development of the districts and the city in general.

\section{Conclusion}

To summarise the literature analysis and observed situation in open public spaces of three modernistic multi-apartment districts in Kaunas the following conclusions can be made:

Strategies for sustainable development of cities will be effective only if a gap between the world of planners and the real world of residents is bridged, where priority is given to the users' space and perspective, not the planners'.

A sociotope mapping is a useful methodology providing a systematic approach for investigation of the real interests and needs of local population / public space users and can be calibrated and 
applied to study the cities that are undergoing complex spatial, social and other transformations.

The current development practice of Lithuanian cities does not assure long-term sustainability; major barriers are the insufficient planning competences and non-participatory culture among professionals and society in general. There is a lack of involvement of community in the planning process and the urban design is not based on the diversity of needs of residents and other local interest groups.

In Kaunas (Lithuania), the spaces of modernist multi-apartment districts can be characterised by the following general features: micro-districts and their internal structures are well-accessible, safe, clean, well maintained. However, the spaces are mostly used for passage or short-term activities. The supply of space features, corresponding to the contemporary way of life of local residents, is too narrow. Currently the majority of the areas offer activities typical for warm weather, daylight, for children and young people (swings, sand boxes, basketball courts, jogging, biking tracks) mostly. It is necessary to include the infrastructure and other conditions that would enable the local actors to use these spaces during all seasons, in morning-day-evening (especially for autumn, winter outdoor activities), they should be attractive to and used by all age groups. It is necessary to develop the conditions for a greater variety of outdoor activities: rest (benches, tables), sharing food (barbecue areas), music, dance, other forms of art; individual or group sports and games (volleyball, ice hockey, skating, swimming, skateboarding, skiing, board games, etc.); observation of wild birds, animals and plants; access to water (fountains, beaches, ponds, springs, etc.). It is also important to encourage the integration of commercial service providers (kiosks, bars). Art objects is another important element (sculptures, street art, artistic lighting, etc.). The spaces should be attractive and used not only by local individuals (residents), but also by locally-based organizations (schools, kindergartens, clubs, enterprises, other public and private institutions).

Improving the possibilities of local users to spend more quality time in nearby open spaces would lead to the creation and strengthening of closer interpersonal relationships, identification and representation of shared interests, sharing of resources, and creation of a stronger local community, thus contributing to a sustainable development of the neighborhood, the city, and the society in general.

\section{ACKNowledgements}

This research was funded by a grant (28 022017 No. S-MOD-17-16/SV3-0364) from the Research Council of Lithuania.

\section{REFERENCES}

1. Global Platform for Sustainable Cities, World Bank. Urban Sustainability Framework. 1st ed. Washington, DC: World Bank. 2018. 160 p.

2. The United Nations. Sustainable Development Goals [online, cited 10.09.2018]. https://www.un.org/sustainabledevelopment/cities/

3. Sumanioji socialinè sistema [Jucevicius, R., Siugzdiniene, J. ed.]. Kaunas: Technologija, 2017. 328 p. https://doi.org/10.5755/e01.9786090213773
4. Urban sustainability issues - Resource-efficient cities: good practice. European Environment Agency, 2015 [online]. European Environment Agency [cited 10.09.2018]. ISBN 978-92-9213-711-3 ISSN 1725-2237 https://doi.org/10.2800/69420

5. Zaleckis, K., Gražulevičiūtè-Vileniškè, I., Vitkuvienè J., Tranavičiūtè, B., Doğan, H. A., Grunskis, T., Sinkienè, J. Integrated socio-spatial analysis of Soviet era modernist urbanization and its consequences in Lithuanian cities: methodological outline. Architecture and Urban Planning, 2017, Vol. 13, pp. 79-84, https://doi.org/10.1515/aup-2017-0011

6. Sinkienè, J. Sumanus miestas ir regionas, Sumanioji socialine siste$m a$ (R. Jucevičius, J. Šiugždinienè ed.). Kaunas: Technologija, 2017. pp. 149-166. https://doi.org/10.5755/e01.9786090213773

7. Global trends: the urban planning process (procedural). Part II. 2010 [online]. UN Habitat [cited 10.09.2018]. https://unhabitat.org/wp-content/ uploads/2010/07/GRHS.2009.2.pdf

8. Are Lithuanian cities and settlements being developed sustainably? Create Lithuania. 2018, August 16 [online]. Kurk Lietuva [cited 10.09.2018] http://kurklt.lt/2018/08/16/miestai-ir-darnus-vystymasis-apklausa/

9. Ståhle, A. Sociotope mapping - exploring public open space and its multiple use values in urban and land-scape planning practice. Nordic Journal of Architectural Research. Volume 19, No 4, 2006, 13 p. http://arkitekturforskning.net/na/article/viewFile/134/105

10. Samuelsson, K., Giusti, M., Peterson, G. D., et al. Impact of environment on people's everyday experiences in Stockholm. Landscape and Urban Planning, 2018, 171, pp. 7-17. https://doi.org/10.1016/j.landurbplan.2017.11.009

11. Ask, E. Att kartlägga sociala värden i stadens utemiljö - Sociotopkartering som metod i Stockholm och Göteborg. Institutionen för Landskapsarkitektur, planering och förvaltning, SLU Alnarp (2013). [online, cited 10.09.2018]. http://stud.epsilon.slu.se/5749/3/ask e 130704.pdf

12. Sociotopkarta. Kungsbacka stad. Sammanställning av observationer, intervjuer och enkätundersökning. Kungsbacka Kommun, Förvaltningen för Teknik. April 2016 [online, cited 10.09.2018]. https://www.kungsbacka.se/ globalassets/gator-trafik-och-utemiljo/dokument/sociotopkarta_sammanstallning.pdf

13. Sollentuna sociotopkarta. Sollentuna Kommun 2014 [online, cited 10.09.2018]. https://www.sollentuna.se/globalassets/trafik--stadsplanering/stadsplanering/urban-gronstruktur/sociotopkarta/sollentuna_sociotopkarta.pdf

14. Sociotopkarta för parker och andra friytor i Stockholms innerstad - om metoden, dialogen och resultatet. Stokholms stadt. Stadsbyggnadskontoret gatu- och fastighetskontoret. Januari 2002.

15. Local Neighbourhood Administrations [online]. Kaunas City Municipality [cited 10.09.2018]. http://www.kaunas.lt/administracija/struktura-ir-kontaktai/seniunijos/

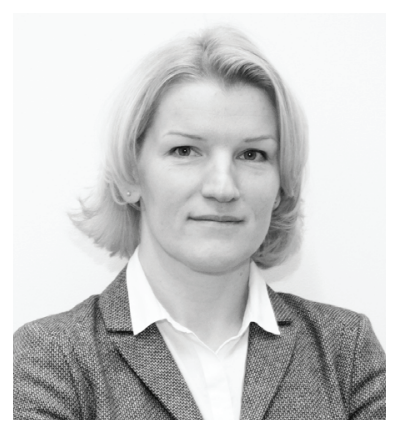

Jolita Sinkienè (b. Kaunas, 1974) is Associated Professor with the Institute of Public Policy and Administration of the Faculty of Social Sciences, Humanities and Arts of Kaunas University of Technology, and Senior Researcher with the Department of Architecture and Urbanism of the Faculty of Civil Engineering and Architecture of Kaunas University of Technology. Her current and previous research interests are urban development policy, urban governance, strategic urban management, vitality of urban communities.

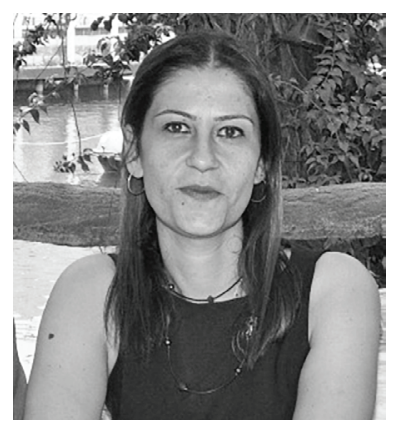

Huriye Armağan Doğan (b. Turkey, 1983) received the degree of Bachelor of Architecture in 2008 and the degree of Master of Restoration and Conservation of Cultural Heritage in 2011. She is currently a PhD Student with the Institute of Architecture and Construction of Kaunas University of Technology. Her research interests are adaptive re-use, preservation of cultural heritage, modern movement, early 20 th century architecture, cultural memory. 


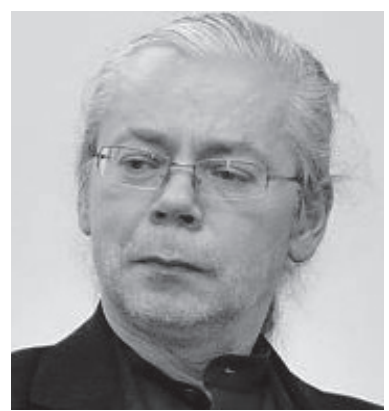

Kęstutis Zaleckis (b. Kaunas, 1969) obtained the Diploma in Architecture in 1992 from Vilnius Gediminas Technical University, the degree of Doctor of Humanities in 2002 from Vytautas Magnus University/ Institute of Architecture and Construction. $\mathrm{He}$ is currently a Professor of the Faculty of Civil Engineering and Architecture of Kaunas University of Technology. His research interests are evolution and mutations of urban spatial genotypes, urban history.

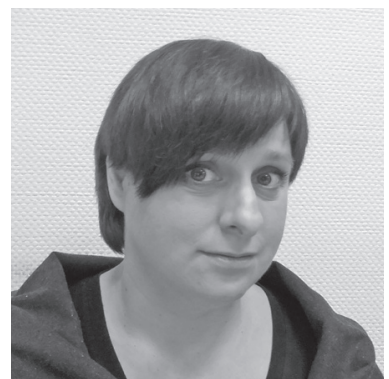

Jurga Vitkuvienė (b. Kaunas, 1976) received the degree of Bachelor of Architecture in 1998 and the degree of Master of Architecture in 2000. Since 2005, she has been a Lecturer with the Faculty of Civil Engineering and Architecture of Kaunas University of Technology. Her research interests are urban history, management of rural-urban interface, urban ecology, sustainable landscape and architecture.

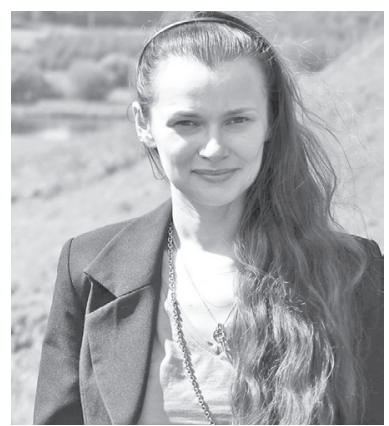

Indrè Gražulevičiūtè-Vileniškè (b. Kaunas, 1981) received the degree of Bachelor of Architecture in 2003, the degree of Master of Land Management in 2005 and the degree of Doctor of Technological Sciences in 2009, from Kaunas University of Technology. From 2009-2012, she was a Lecturer with the Department of Architecture and Land Management of the Faculty of Civil Engineering and Architecture of Kaunas University of Technology. Since 2012, she has been Associated Professor with the Faculty of Civil Engineering and Architecture of Kaunas University of Technology. Her research interests are valuation and preservation of cultural heritage, management of rural-urban interface, sustainable architecture.

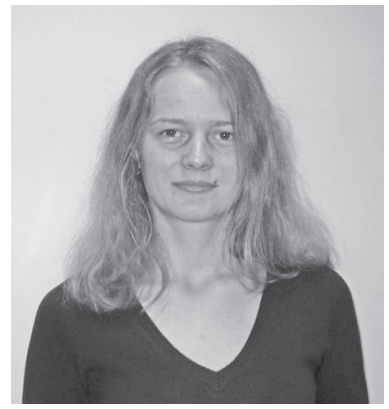

Brigita Tranavičiūtė (b. Kaunas, 1985) received the degree of Bachelor of History in 2007, the degree of Master of Law in 2010, and the degree of Doctor of Humanities in 2015 from Vytautas Magnus University. Since 2016, she has been a Junior Researcher with the Institute of Architecture and Construction of Kaunas University of Technology. Her current and previous research interests are Soviet architecture and urbanism, Soviet economics and trade, post-Soviet economics and trade.

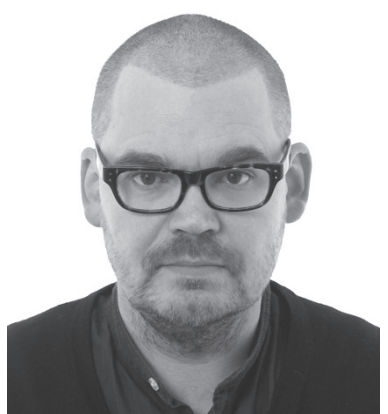

Tomas Grunskis (b. Kaunas, 1972) received the degree of Bachelor of Architecture in 1994, and the degree of Master of Architecture in 1996 from Vilnius Gediminas Technical University. He is Associated Professor with th Department of Architecture of Vilnius Academy of Arts. His current and previous research interests are urban compositions, urban morphology and anthropology, contemporary experimental architecture.

\section{Contact Data}

\section{Jolita Sinkienè}

Kaunas University of Technology, Faculty of Social Sciences, Arts and Humanities

Address: Kaunas University of Technology, Faculty of Social Sciences, Arts and Humanities, 37 A. Mickevičiaus St., Kaunas, Lithuania.

E-mail: jolita.sinkiene@ktu.lt

\section{Huriye Armağan Doğan}

Kaunas University of Technology, Institute of Architecture and Construction. Address: Kaunas University of Technology, Institute of Architecture and Construction, 60 Tunelio St., Kaunas, Lithuania

Phone: +37061670650

E-mail: huriye.dogan@ktu.edu

\section{Kęstutis Zaleckis}

Kaunas University of Technology, Faculty of Civil Engineering and Architecture Address: Kaunas University of Technology, Faculty of Civil Engineering and Architecture, 48 Studentu St., LT-51367 Kaunas, Lithuania

Phone: +370 37451546

E-mail: kestutis.zaleckis@ktu.lt

\section{Jurga Vitkuvienè}

Kaunas University of Technology, Faculty of Civil Engineering and Architecture Address: Kaunas University of Technology, Faculty of Civil Engineering and Architecture, 48 Studentu St., LT-51367 Kaunas, Lithuania

Phone: +370 37451546

E-mail: jurga.vitkuviene@ktu.lt

\section{Indrè Gražulevičiūtè-Vileniškè}

Kaunas University of Technology, Faculty of Civil Engineering and Architecture Address: Kaunas University of Technology, Faculty of Civil Engineering and Architecture, 48 Studentu St., LT-51367 Kaunas, Lithuania

Phone: +37037451546

E-mail: indre.grazuleviciute@ktu.lt

\section{Brigita Tranavičiūtè}

Kaunas University of Technology, Institute of Architecture and Construction. Address: Kaunas University of Technology, Institute of Architecture and Construction, 60 Tunelio St. Kaunas, Lithuania.

E-mail: brigita.tranaviciute@ktu.lt

\section{Tomas Grunskis}

Vilnius Academy of Arts, Department of Architecture

Address: Vilnius Academy of Arts, Department of Architecture, 5 Malūnų St., Vilnius, Lithuania

E-mail: grunskis@gmail.com 